\title{
Metazoan parasite fauna of two peacock-bass cichlid fish in Brazil
}

\author{
Fabio Hideki Yamada ${ }^{1,2^{*}}$ and Ricardo Massato Takemoto ${ }^{1}$ \\ 1 Universidade Estadual de Maringá, Nupelia, Laboratório de Ictioparasitologia, Av. Colombo, 5790, CEP 87020-900, Maringá, PR, Brazil. \\ 2 Universidade Estadual Paulista, Instituto de Biociências, Departamento de Parasitologia, Distrito de Rubião Júnior, s/n, CEP 18.618-000, \\ Botucatu, SP, Brazil. \\ * Corresponding author. E-mail: fhyamada@hotmail.com
}

\begin{abstract}
A parasitological study of two freshwater cichlid fish of the genus Cichla (C. kelberi and C. piquiti) from six different aquatic ecosystems in Brazil was performed. Based on the survey, a checklist of the component community of the metazoan parasites of each of the two peacock-bass fish species was produced. Fish were collected from May 2009 to April 2011 in six Brazilian aquatic ecosystems using gillnets of different mesh sizes or angling using standardized effort. In total, six groups of parasites were collected: Monogenea, Digenea, Cestoda, Nematoda, Copepoda and Branchiura. Among the groups of parasites found, nematodes presented the greatest number of species, with seven. The study lists new records of parasites in C. kelberi and C. piquiti, and new biogeography records of parasites in six different aquatic ecosystems in Brazil. The present paper collaborates with the study of conservation biology by adding new records of parasite species.
\end{abstract}

\section{INTRODUCTION}

Species of the genus Cichla are commonly called peacock-bass in English or tucunaré in Portuguese, accounting for the major piscivorous fish of the Cichlidae family in South America (Lowe-McConnell 1975). They are very popular as sport fish, due to their great voracity in attacking natural or artificial baits and high resistance after being hooked by anglers (Shafland 1996).

This genus is widely distributed in the Amazon, Tocantins and Orinoco river basins, and in the smaller rivers draining the Guianas to the Atlantic Ocean. Within South American transplantations, they are recorded in Paraná and Paraguay River drainages in Paraguay and Brazil, and in Paraíba do Sul and Paraguaçu rivers in Brazil (Kullander and Ferreira 2006). The introduction of these organisms aimed to increase sport fishing, pisciculture and the population control of undesirable and/or highly prolific species (Fontenele and Peixoto 1979; Oliveira et al. 1986). Following their introduction, as a consequence, the peacock-bass dominated in many ecosystems, causing imbalance by demonstrating high competitiveness (Agostinho et al. 2007) and significant ability to reduce populations of native fish (Pelicice and Agostinho 2009).

Studies on parasitic fauna of the genus Cichla have been performed for native populations of the Amazon basin (Kritsky et al. 1989; Thatcher 2006; Araujo et al. 2009) and introduced populations in the Paraná River (Takemoto and Pavanelli 1996; Machado et al. 2000; Santos et al. 2002) and in the Volta Grande reservoir, Grande river, Minas Gerais (Martins et al. 2009). Studies identifying new hosts and new localities for parasites have contributed to the knowledge of local biodiversity as well as the understanding of the evolution of parasites and their hosts (Lacerda et al. 2008). The main purpose of this study was to perform a survey of the metazoan parasites of two peacock-bass fish species from six different aquatic ecosystems in Brazil.

\section{MATERIALS AND METHODS}

Fish were collected from May 2009 to April 2011 from six Brazilian aquatic ecosystems: Marechal Dutra dam (Acauã River) (6 $\left.6^{\circ} 6^{\prime} 11^{\prime \prime} \mathrm{S}, 36^{\circ} 36^{\prime} 17^{\prime \prime} \mathrm{W}\right)$; Lajeado reservoir (Tocantins River) $\left(9^{\circ} 75^{\prime} 14^{\prime \prime} S, 48^{\circ} 35^{\prime} 75^{\prime \prime} W\right)$; São Salvador reservoir (Tocantins River) $\left(12^{\circ} 74^{\prime} 75^{\prime \prime} \mathrm{S}, 48^{\circ} 24^{\prime} 09^{\prime \prime} \mathrm{W}\right)$; Jupiá reservoir (Paraná River) (20 $\left.0^{\circ} 75^{\prime} 98^{\prime \prime} \mathrm{S}, 51^{\circ} 69^{\prime} 50^{\prime \prime} \mathrm{W}\right)$;

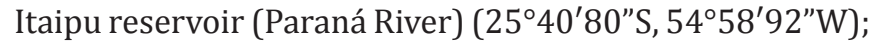
and Rosana reservoir (Paranapanema River) $\left(22^{\circ} 36^{\prime} 08^{\prime \prime} \mathrm{S}\right.$, $52^{\circ} 52^{\prime} 22^{\prime \prime} \mathrm{W}$ ) (Figure 1).

Two species of peacock fish were sampled: Cichla kelberi Kullander and Ferreira, 2006 and C. piquiti Kullander and Ferreira, 2006. Hosts were collected using gillnets of different mesh sizes or angling using standardized effort. After sampling, the gills of the selected individuals were studied for ectoparasites, and the body cavity was opened to examine the liver, stomach, pyloric caeca, intestine and gonads for endoparasites (see Eiras et al. 2006). Sampling, fixation and preservation of parasites were done according to Eiras et al. (2006). Identification of the parasites followed Kritsky et al. $(1986,1989)$, Moravec (1998) and Thatcher (2006). Voucher specimens of parasite species were deposited in the Coleção Helmintológica do Instituto de Biociências de Botucatu (CHIBB), Universidade Estadual Paulista, São Paulo State, Brazil.

\section{RESULTS AND Discussion}

A total of 161 specimens of Cichla, 95 C. piquiti 13 from Jupiá reservoir, 27 from Itaipu reservoir, 25 from Lajeado reservoir and 30 from São Salvador reservoir) and $66 C$. kelberi (21 from Jupiá reservoir, 29 from Rosana reservoir and 16 from Marechal Dutra dam), were examined.

The component community of C. kelberi was composed of four taxonomic groups (Monogenea, Digenea, Cestoda and Nematoda), totalling 863 parasite specimens belonging to 11 taxa, in which Proteocephalus microscopicus (Cestoda) and Contracaecum sp. (larvae) (Nematoda) 
were the most prevalent (Table 1). Cichla piquiti showed a richer and more abundant component community than C. kelberi (Monogenea, Digenea, Cestoda, Nematoda, Copepoda and Branchiura), totalling 21,141 specimens of parasites belonging to 17 taxa, with P. microscopicus (Cestoda) and Gussevia tucunarense (Monogenea) being the most prevalent (Table 2).

\section{Lists of parasite species}

\section{PHYLUM PLATYHELMINTHES Gegenbaur, 1859}

\section{Class Monogenea Van Beneden, 1858}

\section{Order Dactylogyridea Bychowsky, 1937}

\section{Family Dactylogyridae Bychowsky, 1933}

\section{Genus Sciadicleithrum Kritsky, Thatcher and Boeger,} 1989

Sciadicleithrum ergensi Kritsky, Thatcher and Boeger, 1989 - CHIBB 104L, 105L, 106L

Sciadicleithrum uncinatum Kritsky, Thatcher and Boeger, 1989 - CHIBB 110L, 111L
Sciadicleithrum umbilicum Kritsky, Thatcher and Boeger, 1989 - CHIBB 118L, 119L

According to Kritsky et al. (1989), the genus Sciadicleithrum is a Neotropical monogenean, its representatives parasitizing only species of cichlid fishes. Since the genus was first recorded, 13 additional species have been described, totalling 22 species to date. In the present study, $S$. uncinatum and $S$. umbilicum parasitized only $C$. piquiti and $S$. ergensi parasitized both host species.

\section{Genus Gussevia Kohn and Paperna, 1964}

Gussevia tucunarense Kritsky, Thatcher and Boeger, 1986 — CHIBB 107L, 108L, 109L

Gussevia undulata Kritsky, Thatcher and Boeger, 1986 CHIBB 114L

The genus Gussevia parasitizes cichlid fishes of the Neotropical region. Currently, there are 17 valid species in this genus. Despite being parasites of cichlid fishes such as Sciadicleithrum, monogenean species of this genus have a differently shaped haptor with anterior and posterior lobes, hooklets pair 5 with a different morphology. Gussevia tucunarense and $G$. undulata parasitized both host species in the present study.

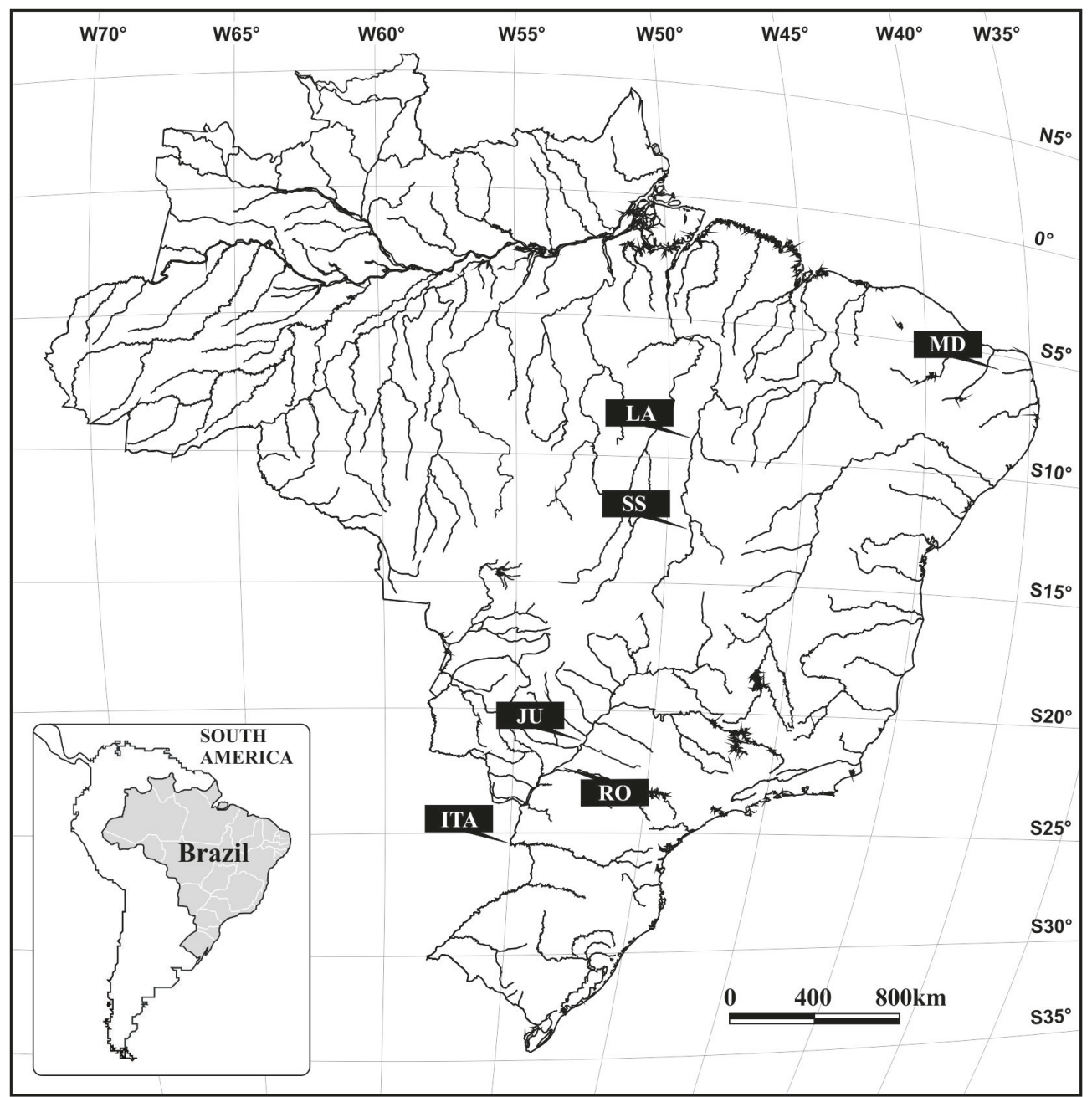

FIGURE 1. Sampling stations of Cichla kelberi and C. piquiti. Label MD (Marechal Dutra dam); LA (Lajeado reservoir); SS (São Salvador reservoir); JU (Jupiá reservoir); RO (Rosana reservoir) and ITA (Itaipu reservoir). 


\section{Class Trematoda Rudolphi, 1808}

Subclass Digenea Carus, 1863

Family Heterophyidae Odhner, 1914

\section{Genus Ascocotyle Looss, 1899}

Ascocotyle sp. (metacercariae) - CHIBB 112L, 113L

Ascocotyle sp. has been already registered, parasitizing many host fish and reaching broad biogeographical distribution (Scholz et al. 1997). Scholz (1999) examined an extensive material and revealed numerous misidentifications of specimens in museum collections and showed a striking similarity between some taxa. Despite their common occurrence, the taxonomy of trematodes of the family Heterophyidae still remains unsatisfactory (Scholz, 1999).

\section{Family Diplostomidae Poirier, 1886}

\section{Genus Sphincterodiplostomum Dubois, 1936}

Sphincterodiplostomum sp. (metacercariae)

According to Lunaschi and Drago (2006), specimens of Sphincterodiplostomum are parasites of the intestine of Neotropical birds. They are monospecific and differ from other genera of the family Diplostomidae by the presence of a dorsal tubular invagination equipped with a sphincter, in the posterior testis. The original description was based on the morphology of immature specimens collected from the intestine of Agamia agami (Gmelin, 1789) (Ardeidae), in Mato Grosso, Brazil. There are records of this parasite in fish organs such as: eyes of Cyphocharax gilbert Quoy and Gaimard, 1824 from the Guandu River (Abdallah et al. 2005) and Hoplias malabaricus Bloch, 1794 from the Upper Paraná River floodplain (Takemoto et al. 2009); in the ovary of Steindachinerina brevipinna Eigenmann and Eigenmann, 1889 from the Paranapanema River (Ceschini et al. 2010); and the visceral cavity of Hemisorubim platyrhynchos (Valenciennes, 1840) from the Upper Paraná River floodplain (Guidelli et al. 2003). The current study recorded Sphincterodiplostomum sp. only in C. piquiti collected from the Itaipu reservoir.

\section{Family Derogenidae Nicoll, 1910}

\section{Genus Genarchella Travassos, Artigas and Pereira, 1928}

Genarchella genarchella Travassos, Artigas and Pereira, 1928

Genarchella genarchella is a type species and parasitizes upper regions of the gut (usually the stomach) of freshwater fish from South and Central America (Thatcher 2006). In the present study G. genarchella parasitized only C. piquiti collected from São Salvador reservoir.
Class CestodaVan Beneden, 1849

Order Proteocephalidea Mola, 1928

Family Proteocephalidae La Rue, 1914

Genus Proteocephalus Weinland, 1858

Proteocephalus microscopicus (Woodland, 1935) - CHIBB 7167

Proteocephalus macrophallus (Diesing, 1850) - CHIBB 7166

Proteocephalids are the most numerous and important helminths in freshwater fish and approximately 80 species have been described in freshwater fish from South America, mostly found in Siluriformes (Rego et al. 1999a). Proteocephalid tapeworms have been studied in several fish species from the Paraná River (Santos et. al. 2011), and P. microscopicus and P. macrophallus were specific of cichlid fish recorded in both hosts of the present study.

\section{Subfamily Corallobothriinae Freze, 1965}

\section{Genus Sciadocephalus Diesing, 1850}

Sciadocephalus megalodiscus Diesing, 1850 - CHIBB 7169

Sciadocephalus megalodiscus was described by Diesing in 1850 parasitizing Cichla monoculus (Bloch and Schneider, 1801) from Mato Grosso State, Brazil, and redescribed by Woodland in 1933 parasitizing the same fish species in Brazilian Amazonia. Rego et al. (1999b) recorded S. megalodiscus parasitizing Cichla monoculus (Cichla kelberi is the valid species) collected in the Paraná River, Brazil. According to Rego (1994), there were doubts about the subfamily to which this species belonged, given that the position of the reproductive organs (a fundamental character to classify the taxon) was unclear, and it was rather treated as a species inquirenda.

PHYLUM NEMATODA Rudolphi, 1808

Class Secernentea Von Linstow, 1905

Order Spirurida Diesing, 1861

Family Camallanidae Railliet and Henry, 1915

Genus Procamallanus Baylis, 1923

Subgenus Procamallanus (Procamallanus) Baylis, 1923

Subgenus Procamallanus (Spirocamallanus) Baylis, 1923

Nematodes of the genus Procamallanus parasitize freshwater and marine fish, and are composed of 
the two subgenera Procamallanus Baylis, 1923 and Spirocamallanus Olsen, 1952. The difference between the two subgenera is basically the aspect of the buccal capsule. Thus, Spirocamallanus presents a buccal capsule with spiral thickenings and Procamallanus shows a smooth buccal capsule. According to Thatcher (2006), Spirocamallanus is probably polyphyletic and may require division into several genera.

Procamallanus (Procamallanus) peracuratus Magalhães Pinto, Fábio, Noronha and Rolas, 1976 - CHIBB 7165

This species was described parasitizing two cichlid fishes: Geophagus brasiliensis (Quoy and Gaimard, 1824) (type host) and Cichlasoma facetum (Jenyns, 1842). Later, it was found in Crenicichla lepidota Heckel, 1840. According to Moravec (1998), it is a parasite mainly in Cichlidae and occasional findings have been reported also from Pimelodus ortmanni Haseman, 1911 (Pimelodidae) and Potamotrygon motoro (Müller and Henle, 1841) (Potamotrygonidae). The present study registered $P$. (P.) peracuratus for the first time parasitizing $C$. kelberi from the Jupiá reservoir.

Procamallanus (Spirocamallanus) rarus Travassos, Artigas and Pereira, 1928

Procamallanus (Spirocamallanus) rarus was described parasitizing the intestine of Pimelodella lateristriga (Lichtenstein 1823) (type host) and Rhynodoras dorbignyi (Kroyer, 1855) in the region of Pirassununga, São Paulo State. Others host species include Pimelodus albicans Valenciennes, 1840, P. clarias (Bloch 1782), P. maculatus Lacépède, 1803, Ageneiosus ucayalensis Castelnau, 1855 and Satanoperca jurupari Heckel, 1840 (Moravec 1998; Giese et al. 2009; Melo et al. 2012). This is the first record of $P$. (S.) rarus parasitizing $C$. piquiti and also the first record in the Paraná River.

Procamallanus (Spirocamallanus) inopinatus Travassos, Artigas and Pereira, 1928 - CHIBB 7171

Takemoto et al. (2009) reported this species in nine different species of hosts in the Upper Paraná River floodplain, Paraná State, Brazil. Moravec (1998) had already registered this species in more than 40 host species, presenting a wide distribution in South American freshwater fish. Araujo et al. (2009) first reported P. (S.) inopinatus in C. kelberi collected in Piauí State, Brazil. The current study reported for the first time the occurrence of this nematode parasitizing C. piquiti from São Salvador reservoir.

\section{Order Ascaridida Skrjabin and Schulz, 1940}

\section{Family Cucullanidae Cobbold, 1864}

\section{Genus Cucullanus Müller, 1777}

Cucullanus sp.

Cucullanus includes approximately 100 species, all parasites of fish around the world (Timi and Lanfranchi 2006). According to Giese et al. (2010) there are 26 known Neotropical species of Cucullanus reported in South America, of which 16 species have been described in Brazil (10 occur in freshwater, five in marine environments and only one species has been described for brackish waters).

\section{Family Anisakidae Railliet and Henry, 1912}

\section{Genus Goezia Zeder, 1800}

Goezia intermedia Rasheed, 1965 - CHIBB 7168

Goezia intermedia is one of the five species of the Goezia genus and parasitizes Neotropical freshwater fish. This species has been described parasitizing C. ocellaris Bloch and Schneider, 1801 (Cichlidae) from Guyana (Georgetown) (Moravec 1998). The present paper reports for the first time $G$. intermedia parasitizing $C$. kelberi and also the first record of it in the Paraná River.

\section{Genus Raphidascaris Railliet and Henry, 1915}

Raphidascaris (Sprentascaris) mahnerti (Petter and Cassone, 1984) - CHIBB 7172

This species parasitizes armoured catfish. This nematode has been registered as Loricaria sp., Loricariichthys sp., L. rostratus Reis and Pereira, 2000, Pseudohemiodon laticeps (=Loricaria laticeps Regan, 1904) in the reservoir of the hydroelectric power plant of Itaipu, Brazil (Kohn et al. 2011), and Loricariichthys platymetopon Isbrücker and Nijssen, 1979 in the upper Paraná River floodplain (Takemoto et al. 2009). In addition to armoured catfish, $R$. (S.) mahnerti has been found to parasitize Metynnis lippincottianus Cope, 1878 (Characidae) (Moreira et al. 2009), Geophagus proximus (Castelnau, 1855) (Cichlidae) (Takemoto et al. 2009) and C. kelberi (Cichlidae) (present study). Moravec et al. (1993) reported a larva from the intestine of the cichlid Geophagus brasiliensis (Quoy and Gaimard, 1824), supposing that this fish probably serves as a paratenic host.

\section{Genus Contracaecum Railliet and Henry, 1912 - larvae - CHIBB 7170}

Adult nematodes of this genus parasitize the digestive tract of birds and marine mammals, while their larvae are often found in the internal organs of fishes serving either as an intermediate or paratenic host (Moravec 1998). In fish hosts the taxonomics and systematics of this parasite are insufficient. Contracaecum spp. (larvae) was recorded in more than 70 hosts of the Neotropical region and in central Mexico. In the present study, this nematode was present in both fish hosts from all the locations.

PHYLUM ARTHROPODA von Siebold and Stannius, 1845

Subphylum Crustacea Pennant, 1777 


\section{Subclass Copepoda Milne Edwards, 1840}

\section{Order Cyclopoida Rafinesque, 1815}

\section{Family Lernaeidae Cobbold, 1879}

Lernaeid (copepodite - immature form) - CHIBB 115L

The first lernaeid found in the Amazon region was described by Thatcher and Paredes (1985). The description was based on specimens from Peru, but the same species has been found in Manaus, Brazil. In recent years, at least seven native species have been found to occur in South America. Amazolernaea sannerae Thatcher and Williams, 1998 is the only lernaeid described parasitizing fish of the genus Cichla (Thatcher 2006). It is possible that the lernaeid found in $C$. piquiti from the Lajeado reservoir is an immature form of Amazolernaea sannerae.

\section{Subclass Branchiura Thorell, 1864}

\section{Family Argulidae Leach, 1819}

\section{Genus Argulus Muller, 1785}

Argulus multicolor Stekhoven, 1937 - CHIBB 116L, 117L

Argulids are ectoparasites of the skin and gills of marine and freshwater fish and are popularly known as 'fish lice'. Argulus multicolor parasitizes seven species of fish in the Amazon region (Thatcher 2006). This is the first record of $A$. multicolor parasitizing $C$. piquiti and in another biogeographic region (Tocantins River - Lajeado reservoir).

One of the main challenges of conservation biology is to estimate biodiversity before some species become extinct. In Brazil, only $17.3 \%$ of fish species have had their parasite fauna recorded, indicating that the total parasite biodiversity of fish in the region is grossly underestimated (Luque and Poulin 2007).

In total, six groups of parasites were collected, mainly Platyhelminthes (Monogenea, Digenea and Cestoda) and Nematoda. Among the groups of parasites found, nematodes presented the greatest number of species, with seven. This is due to a low degree of host specificity presented by the group. Procamallanus (Spirocamallanus) inopinatus has already been identified in 51 fish species in Brazil (Eiras et al. 2010). Kohn et al. (2011) registered a total of 15 species of fish parasitized by $P$. (S.) inopinatus in the Medium Paraná River. Contracaecum sp. (larval stage) was recorded in all localities of the present study. This parasite species deserves special attention because it parasitizes fish as larvae, using it as an intermediate host and then presenting zoonotic potential (Takemoto et al. 2009). Other parasite groups such as Copepoda and Branchiura were present in low prevalence and mean intensity of infestation, recorded only in $C$. piquiti from the Lajeado reservoir located in the Tocantins River. In the present study the Digenea Ascocotyle sp. and Sphincterodiplostomum sp., the Nematoda Contracaecum sp. and the Copepoda Learnaea sp. were identified only at the generic level due to their larval stages.

In general, biogeographic regions exhibit distinct parasite infrapopulations due to various structural strengths. Furthermore, $C$. kelberi and $C$. piquiti in the recent past were introduced in many Brazilian aquatic ecosystems, which could partly explain these differences of parasite component community of these two host population species. In agreement, Torchin et al. (2003) reported a lower parasite diversity in invader regions, where hosts were recently introduced, than in others where they were not, supporting the theory of parasite loss through the invasion process. Kennedy and Bush (1994) argued that the parasite species more easily lost through the invasion process will be the ones more strictly dependent on a narrow range of host taxa to spread out and survive (i.e. more specialized parasites).

TABLE 1. Parasite component community of Cichla kelberi collected in the Jupiá reservoir, Rosana reservoir and Marechal Dutra dam from May 2009 to April 2011.

\begin{tabular}{|c|c|c|c|c|c|c|}
\hline \multirow{2}{*}{ PARASITE SPECIES } & \multicolumn{2}{|c|}{ JUPIÁ RESERVOIR } & \multicolumn{2}{|c|}{ ROSANA RESERVOIR } & \multicolumn{2}{|c|}{ MARECHAL DUTRA DAM } \\
\hline & P (\%) & $\mathrm{MI} \pm \mathrm{SD}$ & $\mathbf{P}(\%)$ & $\mathrm{MI} \pm \mathrm{SD}$ & $\mathrm{P}(\%)$ & $M I \pm S D$ \\
\hline \multicolumn{7}{|l|}{ Ectoparasites } \\
\hline Sciadicleithrum ergensi (Mo) & - & - & 27.58 & $7.87 \pm 13.44$ & - & - \\
\hline Gussevia tucunarense (Mo) & - & - & 6.89 & 1 & - & - \\
\hline Gussevia undulata (Mo) & - & - & 6.89 & 1 & - & - \\
\hline Ascocotyle sp. (metacercariae) (Di) & - & - & 31.03 & $5.44 \pm 4.79$ & - & - \\
\hline Proteocephalus microscopicus (Ce) & 14.29 & $25.33 \pm 28.92$ & 34.48 & $10.10 \pm 11.57$ & 25 & $44.50 \pm 57.63$ \\
\hline Proteocephalus macrophallus (Ce) & - & - & 6.89 & 1 & 12.50 & $26 \pm 21.21$ \\
\hline Sciadocephalus megalodiscus (Ce) & 4.76 & 1 & & - & 6.25 & 1 \\
\hline Procamalanus (Procamalunus) peracuratus $(\mathrm{Ne})$ & 4.76 & 1 & - & - & - & - \\
\hline Goezia intermedia $(\mathrm{Ne})$ & 4.76 & 1 & - & - & - & - \\
\hline Contracaecum sp. (larvae) (Ne) & 52.38 & $26.36 \pm 65.70$ & 3.44 & 1 & 37.50 & $6.83 \pm 12.36$ \\
\hline
\end{tabular}

$\mathrm{P}=$ prevalence; $\mathrm{MI}=$ mean intensity; $\mathrm{SD}=$ standard deviation; $\mathrm{Mo}=$ Monogenea; $\mathrm{Di}=\mathrm{Digenea}$ Ce = Cestoda; $\mathrm{Ne}=\mathrm{Nematoda}$. 
TABLE 2. Parasite component community of Cichla piquiti collected in the Jupiá reservoir, Itaipu reservoir; Lajeado reservoir and São Salvador reservoir from May 2009 to April 2011.

\begin{tabular}{|c|c|c|c|c|c|c|c|c|}
\hline \multirow[t]{2}{*}{ PARASITE SPECIES } & \multicolumn{2}{|c|}{ JUPIÁ RESERVOIR } & \multicolumn{2}{|c|}{ ITAIPU RESERVOIR } & \multicolumn{2}{|c|}{ LAJEADO RESERVOIR } & \multicolumn{2}{|c|}{$\begin{array}{l}\text { SÃO SALVADOR } \\
\text { RESERVOIR }\end{array}$} \\
\hline & $\mathbf{P}(\%)$ & $\mathrm{MI} \pm \mathrm{SD}$ & $\mathbf{P}(\%)$ & $\mathrm{MI} \pm \mathrm{SD}$ & $P(\%)$ & $\mathrm{MI} \pm \mathrm{SD}$ & $P(\%)$ & $M I \pm S D$ \\
\hline \multicolumn{9}{|l|}{ Ectoparasites } \\
\hline Sciadicleithrum ergensi (Mo) & - & - & 66.67 & $10.44 \pm 16.53$ & 92 & $7.13 \pm 6.4$ & 30 & $4.44 \pm 4.61$ \\
\hline Sciadicleithrum uncinatum (Mo) & - & - & 22.22 & $3.83 \pm 2.99$ & 92 & $14.13 \pm 11.21$ & 23.33 & $5.29 \pm 4.31$ \\
\hline Sciadicleithrum umbilicum (Mo) & - & - & - & - & 92 & $66.52 \pm 106.91$ & 33.33 & $4.9 \pm 5.36$ \\
\hline Gussevia tucunarense (Mo) & - & - & 44.44 & $4.75 \pm 5.48$ & 100 & $293.92 \pm 281.97$ & 33.33 & $65.7 \pm 93.74$ \\
\hline Gussevia undulata (Mo) & - & - & 3.7 & 1 & 44 & $4.91 \pm 4.70$ & - & - \\
\hline Ascocotyle sp. (metacercariae) (Di) & - & - & 3.7 & 2 & 72 & $26.61 \pm 43.76$ & - & - \\
\hline Lernaea sp. (copepodite) (Co) & - & - & - & - & 20 & $2.6 \pm 2.61$ & - & - \\
\hline Argulus multicolor (Bra) & - & - & - & - & 8 & $1.5 \pm 0.71$ & - & - \\
\hline \multicolumn{9}{|l|}{ Endoparasites } \\
\hline Genarchella genarchella (Di) & - & - & - & - & - & - & 6.67 & $2.5 \pm 2.12$ \\
\hline $\begin{array}{l}\text { Sphincterodiplostomum sp. (metacercariae) } \\
\text { (Di) }\end{array}$ & - & - & 3.7 & 4 & - & - & - & - \\
\hline Proteocephalus microscopicus (Ce) & 84.62 & $163.82 \pm 338.57$ & 77.78 & $80.48 \pm 116.86$ & 80 & $211.2 \pm 588.65$ & 40 & $70.83 \pm 121.25$ \\
\hline Proteocephalus macrophallus (Ce) & 15.38 & $5.5 \pm 6.36$ & 70.37 & $13.11 \pm 27.19$ & 40 & $3.6 \pm 3.31$ & 6.67 & $2 \pm 1.41$ \\
\hline Sciadocephalus megalodiscus (Ce) & 15.38 & 1 & 11.11 & $81 \pm 137.7$ & 56 & $11 \pm 12.09$ & - & - \\
\hline Procamalanus (Spirocamalunus) rarus $(\mathrm{Ne})$ & - & - & 3.7 & 4 & - & - & - & - \\
\hline $\begin{array}{l}\text { Procamalanus (Spirocamalunus) inopinatus } \\
(\mathrm{Ne})\end{array}$ & - & - & - & - & - & - & 3.33 & 1 \\
\hline Contracaecum sp. (larvae) (Ne) & 38.46 & $29 \pm 62.05$ & 59.26 & $4.38 \pm 5.06$ & 88 & $28 \pm 30.46$ & 36.67 & $3.64 \pm 4.52$ \\
\hline Cucullanus sp. (Ne) & - & - & - & - & 32 & $3 \pm 3.02$ & - & - \\
\hline
\end{tabular}

$\mathrm{P}=$ prevalence; $\mathrm{MI}=$ mean intensity $\mathrm{SD}=$ standard deviation; $\mathrm{Mo}=$ Monogenea; $\mathrm{Di}=$ Digenea; Co = Copepoda Bra = $\mathrm{Branchiura} ; \mathrm{Ce}=\mathrm{Cestoda} ; \mathrm{Ne}=$ Nematoda.

ACKNOWLEDGMENTS: The authors would like to thank Nupelia for logistic support. Fabio Hideki Yamada was supported by CNPq (PhD Scholarship) and currently by the scholarship of the Fundação de Amparo a Pesquisa do Estado de São Paulo (2011/22603-3), and Ricardo Massato Takemoto by CNPq (Productivity Grants).

\section{Literature Cited}

Abdallah, V.D., R.K. Azevedo and J.L. Luque. 2005. Ecologia da comunidade de metazoários parasitos do sairú Cyphocharax Gilbert (Quoy \& Gaimard, 1824) (Characiformes: Curimatidae) do rio Guandu, estado do Rio de Janeiro, Brasil. Revista Brasileira de Parasitologia Veterinária 14(4): 154-159.

Agostinho, A.A., L.C. Gomes and F.M. Pelicice. 2007. Ecologia e manejo de recursos pesqueiros em reservatórios do Brasil. Maringá: EDUEM. 501 p.

Araujo, C.S.O., M.C. Barros, A.L.S. Gomes, A.M.B. Varella, G.M. Viana, N.P. Silva, E.C. Fraga and M.S. Andrade. 2009. Parasitas de populações naturais e artificiais de tucunaré (Cichla spp.). Revista Brasileira de Parasitologia Veterinária 18(1): 34-38.

Ceschini, T.L., R.M. Takemoto, F.H. Yamada, L.H.A. Moreira and G.C. Pavanelli. 2010. Endoparasites of Steindachinerina brevipinna (Eigenmann and Eigenmann, 1889), collected in the tributaries Corvo and Guairacá of Paranapanema river, Paraná State, Brazil. Acta Scientiarum Biological Sciences 32(2): 125-130.

Eiras, J.C., R.M. Takemoto and G.C. Pavanelli. 2006. Métodos de estudo e técnicas laboratoriais em parasitologia de peixes. Maringá: Eduem. $305 \mathrm{p}$.

Eiras J.C., R.M. Takemoto and G.C. Pavanelli. 2010. Diversidade dos parasitas de peixes de água doce do Brasil. Maringá: Clichetec. 333 p.

Fontenele, O. and J.T. Peixoto. 1979. Apreciação sobre os resultados da introdução do tucunaré comum, Cichla ocellaris Bloch \& Schneider, 1801, nos açudes do Nordeste brasileiro, através da pesca comercial. Boletim Técnico Departamento Nacional de Obras Contra Secas 37(2): 109-134.

Giese, E.G., A.P. Furtado, R.M. Lanfredi and J.N. Santos. 2010. A new cucullanid species (Nematoda) from Ageneiosus ucayalensis (Pisces: Auchenipteridae) from Pará, Brazil. Journal of Parasitology 96(2): 389-394.

Giese, E.G., J.N. Santos and R.M. Lanfredi. 2009. A new species of Camallanidae from Ageneiosus ucayalensis (Pisces: Siluriformes) from Pará State, Brazil. Journal of Parasitology 95(2): 407-412.

Guidelli, G., A. Isaac, R.M. Takemoto and G.C. Pavanelli. 2003. Endoparasite infracomunities of Hemisorubim platyrhynchos (Valenciennes, 1840) (Pisces: Pimelodidae) of the Baía river, upper Paraná river floodplain, Brazil: specific composition and ecological aspects. Brazilian Journal of Biology 63(2): 261-268

Kennedy, C.R. and A.O. Bush. 1994. The relationship between pattern and scale in parasite communities: a stranger in a strange land. Parasitology 109: 187-196.

Kohn, A., F. Moravec, S.C. Cohen, C. Canzi, R.M. Takemoto and B.M.M. Fernandes. 2011. Helminths of freshwater fishes in the reservoir of the Hydroelectric Power Station of Itaipu, Paraná, Brazil. Check List 7(5): 681-690.

Kritsky, D.C., V.E. Thatcher and W.A. Boeger. 1986. Neotropical Monogenea. 8. Revision of Urocleidoides (Dactylogyridae, Ancyrocephalinae). Proceedings of the Helminthological Society of Washington 53: 1-37.

Kritsky, D.C., V.E. Thatcher and W.A. Boeger. 1989. Neotropical Monogenea. 15. Dactylogyrids from the gills of Brazilian Cichlidae with proposal of Sciadicleithrum gen. n. (Dactylogyridae). Proceedings of the Helminthological Society of Washington 56: 128-140.

Kullander, S.O. and E.J.G. Ferreira. 2006. A review of the South American cichlid genus Cichla, with descriptions of nine new species (Teleostei: Cichlidae). Ichthyological Exploration Freshwaters 17(4): 289-398.

Lacerda, A.C.F., R.M. Takemoto and G.C.Pavanelli.2008. Digenea, Nematoda, Cestoda, and Acanthocephala, parasites in Potamotrygonidae (Chondrichthyes) from the upper Paraná River floodplain, states of Paraná and Mato Grosso do Sul, Brazil. Check List 4(2): 115-122.

Lowe-McConnell, R.L. 1975. Fish communities in tropical freshwaters. London: Longman. 337 p.

Lunaschi, L. I. and F.B. Drago. 2006. First report of adult specimens of Sphincterodiplostomum musculosum (Digenea, Diplostomidae). Parasitology International 55(1): 7-10.

Luque, J.L. and R. Poulin. 2007. Metazoan parasite species richness in Neotropical fishes: hotspots and the geography of biodiversity. Parasitology 134: 865-878.

Machado, P.M., S.C. Almeida, G.C. Pavanelli and R.M. Takemoto. 2000. Ecological aspects of endohelminths parasitizing Cichla monoculus Spix, 1831 (Perciformes: Cichlidae) in the Paraná River near Porto Rico, State of Paraná, Brazil. Comparative Parasitology 67: 210-217.

Martins, M.L., J. Jr. Pereira, A. De Chambrier and M.M. Yamashita. 2009. Proteocephalid cestode infection in alien fish, Cichla piquiti Kullander and Ferreira, 2006 (Osteichthyes: Cichlidae), from Volta Grande reservoir, Minas Gerais, Brazil. Brazilian Journal of Biology 69: 189195.

Melo, M.F.C., E.G.N. Santos, E.G. Giese, J.N. Santos and C.P. Santos. 2012. Parasites of Satanoperca jurupari (Osteichthyes: Cichlidae) from Brazil. Parasitology Research 110: 389-394.

Moravec, F. 1998. Nematodes of freshwater fishes of the Neotropical Region. Praha: Academy of Sciences of the Czech Republic. $464 \mathrm{p}$

Moravec, F., A. Kohn and B.M.M. Fernandes. 1993. Nematode parasites of 
fishes of the Paraná River, Brazil. Part 2. Seuratoidea, Ascaridoidea, Habronematoidea and Acuarioidea. Folia Parasitologica 40: 115-134.

Moreira, L.H.A., R.M. Takemoto, F.H. Yamada, T.L. Ceschini and G.C. Pavanelli. 2009. Ecological aspects of metazoan endoparasites of Metynnis lippincottianus (Cope, 1870) (Characidae) from Upper Paraná River floodplain, Brazil. Helminthologia 46(4): 214-219.

Oliveira, S.L., Z.C. Mendes, L.C. Crisóstomo and F.G. Araújo. 1986 Resultados preliminares do levantamento ictiológico na represa de Ribeirão das Lajes, estado do Rio de Janeiro. Publicações Avulsas do Museu Nacional do Rio de Janeiro 65: 87-90.

Pelicice, F.M. and A.A. Agostinho. 2009. Fish fauna destruction after the introduction of a non-native predator (Cichla kelberi) in a Neotropical reservoir. Biological Invasions 11: 1789-1801.

Rego, A.A. 1994. Order Proteocephalidae Mola, 1928; p. 257-293 In Khalil, L.F., A. Jones, R.A. Bray. (ed.). Keys to the cestode parasites of vertebrates. St Albans: CAB International.

Rego, A.A., J.C. Chubb and G.C. Pavanelli. 1999a. Cestodes in South American freshwater teleost fishes: keys to genera and a brief description of species. Revista Brasileira de Zoologia 16: 299-367.

Rego, A.A., P.M. Machado and G.C. Pavanelli. 1999b. Sciadocephalus megalodiscus Diesing, 1850 (Cestoda: Corallobothriinae), a parasite of Cichla monoculus Spix, 1831 (Cichlidae), in the Paraná river, State of Paraná, Brazil. Journal of Helminthology 66: 133-137.

Santos, R.S., F.D.A. Pimenta, M.L. Martins, H.K. Takahashi and N.G. Marengoni. 2002. Metacercárias Diplostomum (Austrodiplostomum) compactum Lutz, 1928 (Digenea, Diplostomidae) em peixes do rio Paraná, Brasil. Prevalência, sazonalidade e intensidade de infecção. Acta Scientiarum Biological Science 24: 475-480.

Santos, R.S., K. Roumbedakis, N.G. Marengoni, H.K. Takahashi, F.D.A. Pimenta, C.M.R. Melo and M.L. Martins. 2011. Proteocephalid cestode infection in tucunaré Cichla sp. (Osteichthyes: Cichlidae) from Paraná River, São Paulo. Arquivos Brasileiro de Medicina Veterinária e Zootecnia 63(3): 584-590.
Scholz, T. 1999. Taxonomic study of Ascocotyle (Phagicola) longa Ransom, 1920 (Digenea: Heterophyidae) and related taxa. Systematic Parasitology 43: 147-158.

Scholz, T., J. Vargas-Vázquez, V.M. Vidal-Martínez and L. Aguirre-Macedo. 1997. Ascocotyle nunezae n. sp. (Digenea: Heterophyidae) from Yucatan, Mexico. Journal of Parasitology 83: 141-147.

Shafland, P.L. 1996. An overview of Florida's introduced butterfly peacockbass (Cichla ocellaris) sportfishery. Natura Caracas 96: 2629.

Takemoto, R.M. and G.C. Pavanelli. 1996. Proteocephalidean cestodes in the freshwater fish Cichla monoculus from the Paraná River, Brazil. Studies on Neotropical Fauna and Environment 31: 123-127.

Takemoto, R.M., G.C. Pavanelli, M.A.P. Lizama, A.C.F. Lacerda, F.H. Yamada, L.H.A. Moreira, T.L. Ceschini and S. Bellay. 2009. Diversity of parasites of fish from the Upper Paraná River floodplain, Brazil. Brazilian Journal of Biology 69: 691-705.

Thatcher, V.E. 2006. Amazon fish parasites. Sofia-Moscow: Pensoft, 508 p.

Thatcher, V.E. and V. Paredes. 1985. A parasitic copepod, Perulernaea gamitanae gen. et sp. nov. Cyclopoida: Lernaeidae, from the nasal fosse of a Peruvian Amazon food fish. Amazoniana 9: 169-175.

Timi, J.T. and A.L. Lanfranchi. 2006. A new species of Cucullanus (Nematoda: Cucullanidae) parasitizing Conger orbignianus (Pisces: Congridae) from Argentinean waters. Journal of Parasitology 92: 151-154.

Torchin, M.E., K.D. Lafferty, A.P. Dobson, V.J. Mckenzie and A.M. Kuris 2003. Introduced species and their missing parasites. Nature 421: 628-630.

RECEIVED: April 2013

ACCEPTED: October 2013

PuBlished ONLINE: November 2013

EDITORIAL RESPONSIBILITY: Simone Chinicz Cohen 